\begin{tabular}{lcr} 
FOLIA & $\begin{array}{c}\text { ENTOMOLOGICA } \\
\text { ROVARTANI HÖZLEMÉNYEK }\end{array}$ \\
Volume 81 & 2020 & pp. $81-86$ \\
\hline
\end{tabular}

\title{
Further new and rare weevils in Hungary (Coleoptera: Curculionidae)
}

\author{
Valentin SzÉNÁsI \\ Duna-Ipoly National Park Directorate, H-1021 Budapest, Költö utca 21, Hungary. \\ E-mail:szvalent@gmail.com
}

\begin{abstract}
Trichosirocalus urens (Gyllenhal, 1837) is first recorded from Hungary. Recent, still unpublished Hungarian records of Alcidodes karelinii (Boheman, 1844), Datonychus scabrirostris (Hochhuth, 1847), Leiosoma baudii Bedel, 1884, Minyops costalis (Gyllenhal, 1834), Minyops variolosus (Fabricius, 1775), Mogulonoides radula (Germar, 1823) and Rhinomias viertli (Weise, 1886) are presented. Multiflowered buttercup (Ranunculus polyanthemos L.) is the first host plant species of the two Minyops species. With 6 figures.
\end{abstract}

Key words - Alcidodes, host plants, Minyops, new country records

\section{INTRODUCTION}

The author and his friends are involved in various conservation projects, and during the fieldwork they have the possibility to collect and study the weevil fauna of different areas in Hungary. The present paper publishes locality data of some rare species, including one, which is new to the country, and raises the number of Curculionoidea of Hungary to 1225 (see PoDLUSSÁNy et al. 2019). All specimens were identified by the author.

Abbreviations - PCVS $=$ private collection of Valentin Szénási (Isaszeg, Hungary), HNHM = Hungarian Natural History Museum (Budapest, Hungary). 


\section{A SPECIES NEW TO HUNGARY}

Trichosirocalus urens (Gyllenhal, 1837)

(Fig. 1)

Material examined - Baranya county: Pécsvárad, Aranyhegy, 1.VI.2020,

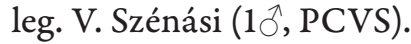

Notes - The species occurs in Europe, North Africa, Near East and Turkey (Asian part) (Alonso-ZAr AZAGa et al.2017). First record for Hungary. Proposed Hungarian name: mediterrán útifüormányos.

\section{NEW RECORDS OF RARE SPECIES}

\section{Alcidodes karelinii (Boheman, 1844)}

Material examined - Bács-Kiskun county: Akasztó, 53-as föút [= main road], 15.VII.2020, leg. V. Szénási (2, PCVS); Csengőd, near Schwarz-major, 15.VII.2020, leg. V. Szénási (3, PCVS); Csengőd, Petőfi Sándor utca, 15.VII.2020, leg. V. Szénási (1, PCVS); Tabdi, near Pogács-dűlő, 15.VII.2020, leg. V. Szénási (2, PCVS).

Notes - The species occurs in Europe (southern Russia, Ukraine) and Far East (Alonso-Zarazaga et al. 2017). It was recorded as new to Hungary in 2019 (SZÉNÁsI \& VÁRI 2019), and since it has been expanding at a rapid pace. On 19 October 2020 Attila László Péntek posted a photo of the species on the website izeltlabuak.hu operated by Balázs Károlyi (“ízeltlábúak" means "arthropods"). The original post is found at https://www.izeltlabuak.hu/talalat/155852, and shows a specimen observed in the residential area $\left(\mathrm{N} 46.3541^{\circ}, \mathrm{E} 18.7094^{\circ}\right)$ of the town Szekszárd (Tolna county). The record proves that the species has already crossed the Danube river and appeared in Transdanubia (the part of Hungary west of the Danube).

\section{Datonychus scabrirostris (Hochhuth, 1847)}

(Fig. 2)

Material examined - Budapest: District XXII, Kamaraerdő, 19.VI.2020, leg. V. Szénási (1, PCVS). - Komárom-Esztergom county: Esztergom, near Kétágú-hegy, 25.IV.2019, leg. V. Szénási (1, PCVS).

Notes - The species occurs in Europe and Caucasian Region (AlonsoZARAZAGA et al. 2017). Very rare in Hungary. 


\section{Leiosoma baudii Bedel, 1884}

(Fig. 3)

Material examined - Pest county: Nagykovácsi, Nagy-Szénás, 25.VI.2020, leg. V. Szénási (1 ${ }^{\Uparrow}$, PCVS).

Notes - The species is know only from Croatia, Hungary, Italy and Switzerland (Alonso-Zarazaga et al. 2017). Second record in Hungary.

\section{Minyops variolosus (Fabricius, 1775)}

(Fig. 4)

Material examined - Baranya county: Pécsvárad, Aranyhegy, 23.IV.2019, 4.V.2019, leg. A. Kotán, V. Szénási (3, PCVS). - Győr-Moson-Sopron county: Dunakiliti, Szára-erdő, 9.V.2020, leg. R. Vidéki (2, PCVS); Dunasziget, SzigetiDuna-töltés [= dyke], 1.V.2020, leg. R. Vidéki (3, PCVS); Fertőszéplak, halastavak [= fish ponds], 25.IV.2009, leg. B. Szelenczey (2, PCVS). - Heves county: Gyöngyöspata, Meggyes, 7.V.2020, leg. V. Szénási (2, PCVS, 1, HNHM). Komárom-Esztergom county: Esztergom, Kincses-hegy, 14.V.2020, leg. V. Szénási (2, PCVS). - Fejér county: Belsőbáránd, Bárándi-gyepek, 29.V.2008, leg. S. Bérces (1, PCVS). - Pest county: Biatorbágy, Katalin-hegy, 6.IV.2005, leg. A. Kotán (1, PCVS); Csobánka, Kőpor, 2.VI.2020, leg. V. Szénási (2, PCVS); Galgamácsa, near Csuzi-rét, 15,IV.2019, leg. V. Szénási (2 PCVS); Galgamácsa, Galga-mente, 24,IV.2010, leg. V. Szénási (1, PCVS); Kisoroszi, Nagy-Cseres, 18.IV.2020, leg. V. Szénási (4, PCVS); Kisoroszi, Csereklyés, 18.IV.2020, leg. V. Szénási (4, PCVS); Kisoroszi, Duna-gát, 18.IV.2020, leg. V. Szénási (1, PCVS); Nagykáta, Disznótúrási-tó, 3.V.2018, leg. V. Szénási (5, PCVS); Nagykáta, Göbölyjárás, 3.V.2018, leg. V. Szénási (3, PCVS); Nagykáta, Nyík-rét, 3.V.2018, leg. V. Szénási (2, PCVS); Nagykáta, Meggyeshalmi-rét, 7.V.2018, leg. V. Szénási (2, PCVS); Pomáz, Dugacske, 14.V.2020, leg.V.Szénási (2, PCVS); Rád, Drága-hegy, 1.V.2019, leg. V. Szénási (2, PCVS); Tápióbicske, Sajgó, 8.V.2018, leg. V. Szénási (3, PCVS); Vác, Kecskések, Nyulas-dűlő, 10.V.2020, leg. T. Németh (1, PCVS). Vác, Kis Sejce, 8.IV.2019, leg. V. Szénási (1, PCVS); Váckisújfalu, Szélesek, 4.V.2016, 4.IV.2017, 27.IV.2017, 2.V.2018, 8.IV.2019, leg. T. Németh \& V. Szénási (12, PCVS, 2, HNHM); Visegrád, Cukor-rét, 2.V.2020, leg. V. Szénási (3, PCVS). - Veszprém county: Vilonya, Külső-hegy, 1.V.2015, leg. V. Szénási (1, PCVS).

Notes - The species is distributed from easternmost France to western and central Hungary and the western Balkan Peninsula (Osella \& Bello 2010). It is considered rare in the Hungarian literature. However, targeted search resulted in several new records, and the species is in fact not uncommon. Its host plants was unknown by OSELLA \& BELLO (2010), but the targeted search revealed that it must be Ranunculus polyanthemos L., because all specimens collected since 2015 were found feeding or laying eggs on that plant species. 


\section{Minyops costalis (Gyllenhal, 1834)}

Material examined - Békés county: Battonya, Kistompapuszta, 15.V.2020, leg. A. Kotán, A. Márkus, T. Németh \& V. Szénási (10, PCVS, 2 HNHM).

Notes - The species is distributed from easternmost Germany to Romania and Ukraine (OSELLA \& BeLlo 2010). In Hungary, it seems to be restricted to Dél-Tiszántúl (the southeastern part of the Great Hungarian Plain) (MER KL et al. 2014). Its host plant must also be Ranunculus polyanthemos L., because the abovementioned individuals were collected from that plant species.

\section{Mogulonoides radula (Germar, 1823)}

(Fig. 5)

Material examined - Pest county: Dabas, Halász-domb, 15.X.2020, leg. V. Szénási (12, PCVS); Dabas, Vizes-Nyilas, 17.X.2020, leg. V. Szénási (4, PCVS); Domony, Bárányjárás 22.X.2020, leg. V. Szénási (2, PCVS); Dunakeszi, Ábrahám Pál utca, 1.XI.2020, leg. A. Kotán (2, PCVS); Farmos, gátőrház, 18.X.2020, leg. V. Szénási (2, PCVS); Isaszeg, Bartók Béla utca 36, 16.X.2020, leg. V. Szénási (3, PCVS); Kistarcsa, Küdői-hegy, 22.X.2020, leg. V. Szénási (1, PCVS); Ócsa, Alsónémedi út, 5.IX.2014, leg. A. Kotán (1, PCVS); Pécel, Trianon-emlékmü 22.X.2020, leg. V. Szénási (3, PCVS); Tatárszentgyörgy, XX. csatorna mente. 17.X.2020, leg. V. Szénási (2, PCVS).

Notes - The species occurs in Europa and Turkey (Asian part) (AlonsoZARAZAGA et al. 2017). It is considered rare in the Hungarian literature, however, targeted search resulted in several new records. All collected specimens were observed while feeding and laying eggs on Anchusa officinalis L., which must be the host plant of the species.

Rhinomias viertli (Weise, 1886)

(Fig. 6)

Material examined - Baranya county: Pécs, Tolvaj-gödör, 12.VII.2020, leg. V. Szénási (2, PCVS).

Notes - The species is known only from Austria, Croatia, Hungary and Romania (Alonso-ZARAZAGA et al. 2017). Very rare in Hungary. 

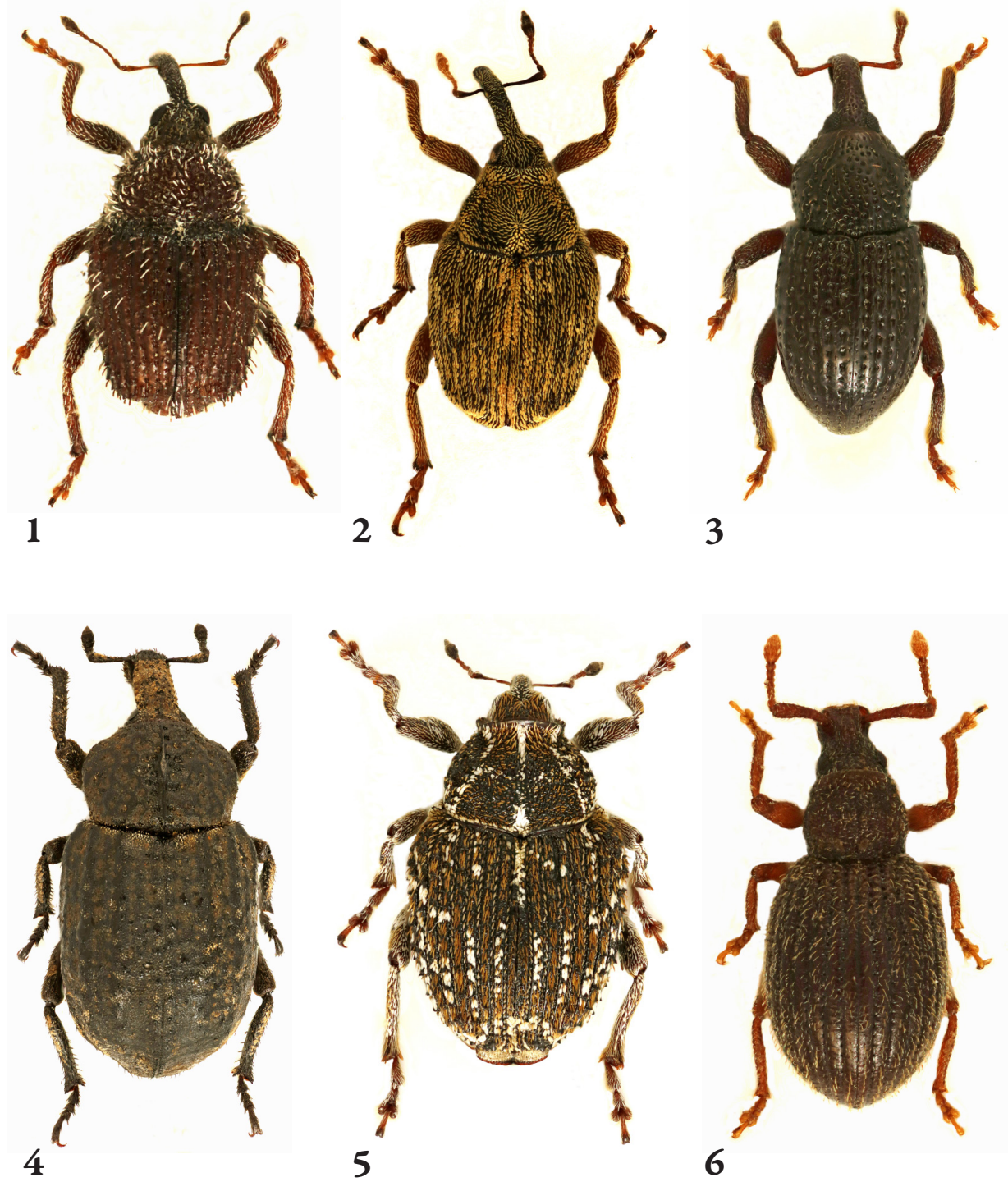

Figs 1-6. 1 = Trichosirocalus urens (Gyllenhal, 1837), 2 = Datonychus scabrirostris (Hochhuth, 1847), 3 = Leiosoma baudii Bedel, 1884, $4=$ Minyops variolosus (Fabricius, 1775), 5 = Mogulonoides radula (Germar, 1823), 6 = Rhinomias viertli (Weise, 1886). Not to scale (photos by Valentin Szénási) 
Acknowledgements - I would like to thank all those who contributed to the compilation of this study. Thanks are due to Ottó Merkl (HNHM) for the possibility to review the relevant part of HNHM Coleoptera Collection so that I could use it for my paper; and to Sándor Bérces, Attila Kotán, Tamás Németh, Béla Szelenczey and Róbert Vidéki who collected weevils for me.

\section{REFERENCES}

Alonso-Zarazaga M. A., Barrios H., Borovec R., Bouchard P., Caldara R., Colonnelli E., Gülte kin L., Hlaváč P., Korotyaev B., Lyal C. H. C., Machado A., Meregalli M., Pierotti H., Ren L., Sánchez-Ruiz M., Sforzi A., Silfferberg H., Skuhrovec J., Trýzna M., Velázeuez de Castro A. J. \& Yunakov N. N. 2017: Cooperative Catalogue of Palaearctic Coleoptera Curculionoidea. Monografías electrónicas SEA, vol. 8. - Sociedad Entomológica Aragonesa (S. E. A.), Zaragoza, 729 pp.

Merkl O., KöDöвöcz V., Deli T. \& DanyiK T. 2014: Bogárfaunisztikai adatok a DélTiszántúlról (Coleoptera). (Faunistic data to the beetles from the south-eastern Great Hungarian Plain (Coleoptera).) - Crisicum 8: 99-152.

Osella G. \& Bellò C. 2010: Revisione di Minyops Schoenherr, 1823 e Paraminyops nov. gen. (Coleoptera, Curculionidae, Molytinae). - Memorie del Museo Civico di Storia Naturale di Verona, 2. Serie, Sezione Scienze della Vita 19: 3-133.

Podlussány A., SzénÁsi V. \& Merkl O. 2019: Checklist of the Curculionoidea of Hungary (Coleoptera). - Folia entomologica hungarica 80: 89-230.

https://doi.org/10.17112/FoliaEntHung.2019.80.89

SzÉnÁsI V. \& VÁRI G. 2019: Alcidodes karelinii new to Hungary (Coleoptera: Curculionidae: Molytinae). - Folia entomologica hungarica 80: 83-87.

https://doi.org/10.17112/FoliaEntHung.2019.80.83 